International Journal on Integrating Technology in Education (IJITE) Vol.2, No.1, March 2013

\title{
Socio-demographic Profile and Career Choice of Science Students: A study of Science Students of University of Pune, Pune, India.
}

\author{
Dr. Mohsin R Shaikh \\ Professor and Head, Department of Management Studies, \\ STES, Smt. Kashibai Navale College of Engineering, Pune, India \\ Email:skmohsinlerediffmail.com
}

\begin{abstract}
:
The growth and development of any country depends upon the pool of scientific and technical manpower available in the country. There is deterioration in the quality and quantity of students pursuing their education in the field of basic sciences. The current study aims to understand the demographic profile, motivational factors, aspirations and career choices of science students of University of Pune. This study will help us in understanding the aspirations, career choices and problems faced by them. This understanding will be helpful in undertaking measures to attract more students to pursue education and careers in sciences, improve the quality of science students and help in increasing the pool of scientific and technological manpower in the state and the country which is vital for sustainable economic growth and development.
\end{abstract}

\section{Keywords:}

Science Education, Demographic Profile, Career Choice, University of Pune.

\section{Introduction:}

The economic growth and development of any nation depends upon the human resource development initiative undertaken by the country. With sectorial changes taking place in the Indian economy, the contribution of the tertiary sector today is more than fifty per cent to the GDP of the nation. This sector requires a different set of skills and its growth depends upon creativity and innovation. The rapid development of the Chinese economy has been attributed to the human resource development in the science and technology sector. The science graduates who are unemployed comprise 22.30 percent of all unemployed graduates. The share of science post graduates among the total unemployed post graduates is a high of 62.8 percent

The concept of human resource development in general and the development of science and technology manpower in particular has been one of the most discussed and researched topic in the current era of globalization and knowledge economy. Many countries have undertaken many national level studies on the stock of scientific and technology manpower, attitude of students and parents towards science education and the contribution of science and technology manpower in venture creation and economic growth and development. The United States undertook a nationwide survey of parent's attitude towards science education in USA. The survey dealt with the attitude of parents towards science education and whether they felt that science education was important for their child's future in a globally competitive workforce. The UK parliamentary committee on science and technology education commissioned a study on the contribution of science and DOI : $10.5121 /$ ijite.2013.2101 
International Journal on Integrating Technology in Education (IJITE) Vol.2, No.1, March 2013

mathematics graduates in new venture creation. Besides this almost all the countries prepare and publish their national science reports to take stock of the science and technology pool in their country.

\section{Status of Science Education in India:}

Despite impressive growth in the numbers, percentage of students opting for science after $10+2$ has declined from $31 \%$ in fifties to around $20 \%$ during nineties.However, today the lower middle level 20\% students opt for science. There is an unmistakable growing trend of brighter boys and girls shying away from science. Even those who win International Olympiad Medals are reluctant to opt for career in science. This trend is further substantiated by a comparatively lower percentage of marks needed for admission to science stream in our colleges as compared to other professional streams.

A large number, nearly $90 \%$ of undergraduate students in sciences are educated in affiliated colleges. Most of these colleges are overcrowded, underequipped in laboratory and library facilities and are also poorly staffed. Classroom demonstrations and open-ended experimentation have all but disappeared from the undergraduate science education programmes, despite the fact that science is truly experiment based and is an endless exploration. There is presently nothing in the system that excites the curiosity of young minds, communicates a sense of excitement in doing science, nourishes and nurtures creativity and innovativeness, imparts necessary skills and generates self-confidence. All this results in not only an alarming rate of

dropouts and fallouts, as high as $40 \%$, but also in our young boys and girls emerging out of colleges devoid of curiosity, unexcited and unimaginative, lacking in creativity and self confidence and frightful of their future. There are of course, few institutes that still heroically seek to offer science education comparable to that available in advanced countries. However, they are confronted with outdated curricula and also rigidity of the institutional set up and of the universities to which they are affiliated, and are thus unable to make any significant impact on the general scene.

Poor undergraduate science education programmes have led to still poorer post-graduate science education programmes. This clearly presents two related problems. A large number of talented students simply do not opt for a career in science because they do not consider it as rewarding and satisfying. At the same time, a large number of unmotivated and uninterested students crowd in our science colleges. Thus the present system has neither the selectivity nor the atmosphere conducive to motivation, innovation and creativity. The consequences of all this are obvious and unmistakable. If this trend continues, even strategically important sectors such as space, atomic energy, defense, biotechnology etc., will find it difficult to recruit young scientists of high caliber needed for these nationally important programmes. In fact, many of these institutions have already lowered their selection criterion. In addition, standards of teaching of science would further decline.

All this manifests itself in several ways. There is a decrease in research productivity in the country in most scientific disciplines. Science and technology output indicators such as publication of research papers and filling of patents are stagnant or decreasing compared to those of even South Korea, China etc. The centre of gravity of research and development in science and technology has therefore shifted from teaching and academic institutions to bureaucratic research institutions. This is not sustainable. It is only the face to face confrontation and critical dialogue between experienced professors and their bright inquisitive students, without the constraints and inhibitions that generally operate in the non-university type system that provides stimulus to original thinking and to the expansion of the horizons of human knowledge. The wisdom and the 
International Journal on Integrating Technology in Education (IJITE) Vol.2, No.1, March 2013

knowledge of one and the desire to surpass on part of the other provide the right combination in the universities for their mutual growth. It is the only recipe to build science. Science teaches /education and research must be inextricably linked. In the absence of clear perception and adequate realization of the mechanism of building self-generating, sustainable and enduring base for science, we have dried the source and resource that feeds into the system of research and technology development. With research only in research laboratories, in the absence of a steady flow of well talented and innovative young boys and girls, we are making our research laboratories unproductive. Indeed, National research institutions and agencies are facing an acute shortage of quality manpower. This problem would become very critically 2010 .

\section{Method:}

The study was carried out using primary and secondary data. The sample population for the study included all senior colleges affiliated to University of Pune offering B.Sc and M.Sc courses. There are 128 colleges offering B.Sc courses affiliated to University of Pune in Pune, Ahmednagar and Nasik district.

The sample size for the study included 250 students 30 colleges from urban and rural areas from the districts of Pune, Ahmednagar and Nasik using stratified random sampling technique. The final usable questionnaires were 195 out of 250 as over 55 questionnaires were found to be incomplete or incorrect. The instrument for data collection was a structured questionnaire which was administered to the students of the selected colleges.

The secondary data was collected from the annual reports of the University, colleges, Government publications, reports, journals, magazines and the internet. The data collected was analysed using various statistical tools and SPSS 18.0 software.

\section{Objectives of the study:}

i) To find the socio demographic profile of the science students studying in different science colleges affiliated to University of Pune.

ii) To understand the motivational factors that attracts students towards science education

iii) To find out the relationship between demographic profile and career choice of the students

\section{Results:}

The major socio- demographic factors considered in the research were; gender, medium of instruction at secondary school level and the background of the students. The factors that motivated students to peruse science education were identified by asking the respondents to mark the factors that motivated tem o take admission in science discipline. In order to find their career preference they were asked about the career and the courses they plan to take after completing their graduation in science (B.Sc).

It was found that majority of the students perusing science education were females (Table1).This could be due to the fact that one of the college included in the study was a women's college and hence all the respondents from the said college were females. This might have increased the proportion of female's respondents in the sample. As regards medium of instruction of the students at secondary school level it was found that the students opting for science education come equally from regional (Marathi) medium (48 percent) and from English medium (46 percent), only about 6 percent of the students were from other medium (Urdu). The analysis of the background of the study revealed that majority of the students opting for science education are from urban area ( 73 percent) where as only 27 percent of the students were from rural area. 
International Journal on Integrating Technology in Education (IJITE) Vol.2, No.1, March 2013

This supports the finding of the National Science report that most of the rural students opt for Arts courses.

The analysis of the career choice of the students at the time of higher secondary school study found that majority of the students (70 percent) were interested in studying science (B.Sc) ,followed by medical (13 percent) and engineering (11 percent) (Table 2). When asked about the reason for studying science majority of the students (61 percent) replied that they are studying science due their interest in the subject, where as about 20 percent said they were studying science as they did not get admission in engineering or medical courses (Table 3). It was found that majority of the students after completing their graduation in science (B.Sc.) were interested in doing their post graduation in science (M.Sc.), followed by job and other post graduate courses like MBA, MCA etc. (Table 4).

The Chi square test to find out the relation between gender and reason for studying science revealed that there is no association between gender and studying science. $(\mathrm{N}=119, \mathrm{df}=4, \mathrm{P}=0.15)$ (Table 5). Similarly there was no association between gender and plan after graduation $(\mathrm{N}=119$, $\mathrm{DF}=6, \mathrm{P}=0.64)$ and between medium of instruction and plan after science degree $(\mathrm{N}=119$, $\mathrm{DF}=24, \mathrm{P}=0.11$ ), (Tables 5 and 6.).

\section{Discussion:}

The study brings out some interesting findings about the demographic profile of the students studying science, the factors that motivate them to pursue science education and their career choice after science education. The fact that males are more attracted to science education has not been proved in the study. The study in fact found more females students perusing science education than males. However as pointed out earlier the inclusion of a women's college in the study might have affected the proportion of females in the sample. Another factor worth considering is the proportion of students from Marathi medium pursuing science education was slightly more than those who have studied in English medium. Hence efforts should be made equally among English as well as Marathi medium schools to motivate students into science education. The finding that majority of the students undergoing science education come from urban areas is quite disturbing, this confirms the finding of the national science report that students from rural background prefer Arts subjects than science. Sincere efforts should to be taken to make science education attractive, assessable and affordable to students from rural areas.

The finding about the reasons for taking science education is encouraging. Majority of the students are pursuing science education due to their interest in the subject; however there are some who take admission in science courses as they do not get admission for medical and engineering. Also majority of the students after completing graduations in science were interested in doing their post graduation in science, however there were some who were interested in other professional post graduate courses like management and computer applications.

No relationship was found between gender and studying science and plan after graduation. Also no relationship was found between medium of instruction and plan after science graduation. This shows that these demographic factors have no relation as far as making a career choice is concerned. 


\section{Conclusion:}

The present study is one of the first of its kind. The study throws some light on the demographic factors like gender, urban rural background and medium of instruction as well as the aspirations of the student after completing their science graduation. The study being conducted for students of only a single university has the limitations of being of local /regional level. However a similar kind of study at regional or national level may be conducted to get the large picture. The finding of the study may be of help for policy makers and all those interested in promoting science education in India and making it a scientific and technological super power.

\section{References:}

- Bkarr, D. and Leary, R. (1995). Letting girls speak out about science. Journal of Research in Science Teaching, 32, 3-27.

- Barnett, C. (2001). Prelude to an industrial defeat from the 1944 Education Act to the 1956 Whitepaper on Technological Education (London: Royal Society of Arts).

- Beaton, A., Martin, M. O., Mullis, I., et.al. (1996).Science achievement in the middle school years: IEA's Third International Mathematics and Science Study (Chestnut Hill, MA: Boston College).

- Becker, B. J. (1989). Gender and science achievement: Is analysis of studies from two metaanalyses.Journal of Research in Science Teaching, 26, 141-169.

- Cheng, Y., Payne, J. and Witherspoon, S. (1995). Science and mathematics in full-time education after 16: England and Wales Youth Cohort Study (London: Department for Education and Employment).

- Cooper, P. and Mcintyre, D. (1996). Effective teaching and learning: teachers' and students' perspectives (Buckingham: Open University Press).

- Education Policy commission (1962). Education and the spirit of science (Washington, DC: Education Policies Commission).

- India Science Report, Science Education, Human Resources and Public Attitude towards Science

- and Technology, National Council of Applied Economic Research, National Council of Applied Economic Research, 2005

- Maple, S.A., \& Stage, F.K. (1991). Influences on the Choice of Math/Science Major by Gender and Ethnicity. American Educational Research Journal, 28(1): 37-60.

- Roddam Narsimha (2008), Science, Technology and the Economy an Indian Perspective, Technology in Society, 2008, 30:330-338.

- Simpson, R.D., \& Oliver, J.S. (1985). Attitude Toward Science and Achievement Motivation Profiles of Male and Female Science Students in Grades Six Through Ten. Science Education, 69(4): 511-526.

\section{Acknowledgements:}

The author would like to thank the Board for College and University Development, University of Pune for providing financial assistance in carrying out this research project. The author is also grateful to all the principals, faculty members and students for their help in providing the data required for the project. 
International Journal on Integrating Technology in Education (IJITE) Vol.2, No.1, March 2013

\section{Tables and Graphs:}

Table 1

Demographic Profile of the students

\begin{tabular}{|l|c|c|c|c|}
\hline \multirow{2}{*}{ Gender } & Male & \multicolumn{3}{|c|}{ Female } \\
\cline { 2 - 5 } & $34.4 \%$ & \multicolumn{3}{|c|}{$65.6 \%$} \\
\hline \multirow{2}{*}{ Class studying } & FY & SY & \multicolumn{2}{|c|}{ TY } \\
\cline { 2 - 5 } & 35.4 & $20.0 \%$ & \multicolumn{2}{|c|}{$44.6 \%$} \\
\hline \multirow{2}{*}{ Medium at SSC } & Marathi & English & Urdu & Other \\
\cline { 2 - 5 } & $47.7 \%$ & $45.6 \%$ & $5.6 \%$ & $1.0 \%$ \\
\hline \multirow{2}{*}{ Background } & Rural & \multicolumn{3}{|c|}{ Urban } \\
\cline { 2 - 5 } & $27.2 \%$ & \multicolumn{3}{|c|}{$72.8 \%$} \\
\hline
\end{tabular}

Table 2

PLAN AFTER HSC ( 1- Engineering, 2- Medical, 3- B.Sc. , 4 - Armed forces, 5- Competitive exams, 6- Others)

\begin{tabular}{|c|c|c|c|c|c|}
\hline & & Frequency & Percent & Valid Percent & Cumulative Percent \\
\hline \multirow{7}{*}{ Valid } & 1 & 21 & 10.8 & 10.8 & 10.8 \\
\hline & 2 & 25 & 12.8 & 12.8 & 23.6 \\
\hline & 3 & 136 & 69.7 & 69.7 & 93.3 \\
\hline & 4 & 4 & 2.1 & 2.1 & 95.4 \\
\hline & 5 & 5 & 2.6 & 2.6 & 97.9 \\
\hline & 6 & 4 & 2.1 & 2.1 & 100.0 \\
\hline & Total & 195 & 100.0 & 100.0 & \\
\hline
\end{tabular}

\section{Graph 1}

Table 3

REASON FOR DOING BSC ( 1- Interest, 2- Scientist, 3- Parents wish, 4- Not got admission in Engg / Medical, 5- Business, 6- Others)

\begin{tabular}{|c|c|c|c|c|c|}
\hline & & Frequency & Percent & Valid Percent & Cumulative Percent \\
\hline \multirow{6}{*}{ Valid } & 1 & 119 & 61.0 & 61.0 & 61.0 \\
\hline & 2 & 12 & 6.2 & 6.2 & 67.2 \\
\hline & 3 & 14 & 7.2 & 7.2 & 74.4 \\
\hline & 4 & 38 & 19.5 & 19.5 & 93.8 \\
\hline & 5 & 12 & 6.2 & 6.2 & 100.0 \\
\hline & Total & 195 & 100.0 & 100.0 & \\
\hline
\end{tabular}


International Journal on Integrating Technology in Education (IJITE) Vol.2, No.1, March 2013

\section{Graph 2}

Table 4

PLAN AFTER BSC (1- Job, 2- M.Sc, 3- Other PG, 4- Competitive exam, 5- Business, 6- Others)

\begin{tabular}{|c|c|c|c|c|c|}
\hline & & Frequency & Percent & Valid Percent & Cumulative Percent \\
\hline \multirow{8}{*}{ Valid } & 0 & 2 & 1.0 & 1.0 & 1.0 \\
\hline & 1 & 23 & 11.8 & 11.8 & 12.8 \\
\hline & 2 & 119 & 61.0 & 61.0 & 73.8 \\
\hline & 3 & 21 & 10.8 & 10.8 & 84.6 \\
\hline & 4 & 13 & 6.7 & 6.7 & 91.3 \\
\hline & 5 & 9 & 4.6 & 4.6 & 95.9 \\
\hline & 6 & 8 & 4.1 & 4.1 & 100.0 \\
\hline & Total & 195 & 100.0 & 100.0 & \\
\hline
\end{tabular}

\section{Graph 3}

\section{Table 5}

Count

Crosstab

\begin{tabular}{|c|c|c|c|c|c|c|}
\hline & \multicolumn{5}{|c|}{ REASON FOR DOING BSC } & \multirow[t]{2}{*}{ Total } \\
\hline & 1 & 2 & 3 & 4 & 5 & \\
\hline & 37 & 3 & 5 & 14 & 8 & 67 \\
\hline GENDER & 82 & 9 & 9 & 24 & 4 & 128 \\
\hline Total & 119 & 12 & 14 & 38 & 12 & 195 \\
\hline
\end{tabular}

Chi-Square Tests

\begin{tabular}{|l|r|r|rr|}
\hline & \multicolumn{1}{|c|}{ Value } & \multicolumn{1}{|c|}{ df } & Asymp. Sig. (2-sided) \\
\hline Pearson Chi-Square & $6.698^{\mathrm{a}}$ & 4 & .153 \\
Likelihood Ratio & 6.362 & 4 & .174 \\
Linear-by-Linear & 3.477 & 1 & .062 \\
Association & 195 & & \\
N of Valid Cases & & & \\
\hline
\end{tabular}

3 cells $(30.0 \%)$ have expected count less than 5 . The minimum expected count is 4.12 . 
International Journal on Integrating Technology in Education (IJITE) Vol.2, No.1, March 2013

\section{Table 6}

\section{Crosstab}

Count

\begin{tabular}{|c|c|c|c|c|c|c|c|c|c|}
\hline & \multicolumn{7}{|c|}{ PLAN AFTER BSC } & \multirow[t]{2}{*}{ Total } \\
\hline & & 0 & 1 & 2 & 3 & 4 & 5 & 6 & \\
\hline \multirow{3}{*}{$\begin{array}{l}\text { GENDER } \\
\text { Total }\end{array}$} & 1 & 0 & 9 & 40 & 5 & 5 & 5 & 3 & 67 \\
\hline & & 2 & 14 & 79 & 16 & 8 & 4 & 5 & 128 \\
\hline & & 2 & 23 & 119 & 21 & 13 & 9 & 8 & 195 \\
\hline
\end{tabular}

Chi-Square Tests

\begin{tabular}{|c|c|c|c|}
\hline & Value & df & Asymp. Sig. (2-sided) \\
\hline $\begin{array}{l}\text { Pearson Chi-Square } \\
\text { Likelihood Ratio } \\
\text { Linear-by-Linear Association } \\
\mathrm{N} \text { of Valid Cases }\end{array}$ & $\begin{array}{r}4.270^{\mathrm{a}} \\
4.858 \\
.538 \\
195\end{array}$ & $\begin{array}{l}6 \\
6 \\
1\end{array}$ & $\begin{array}{l}.640 \\
.562 \\
.463\end{array}$ \\
\hline
\end{tabular}

a. 5 cells $(35.7 \%)$ have expected count less than 5 . The minimum expected count is .69 .

\section{Table 7}

\section{Crosstab}

Count

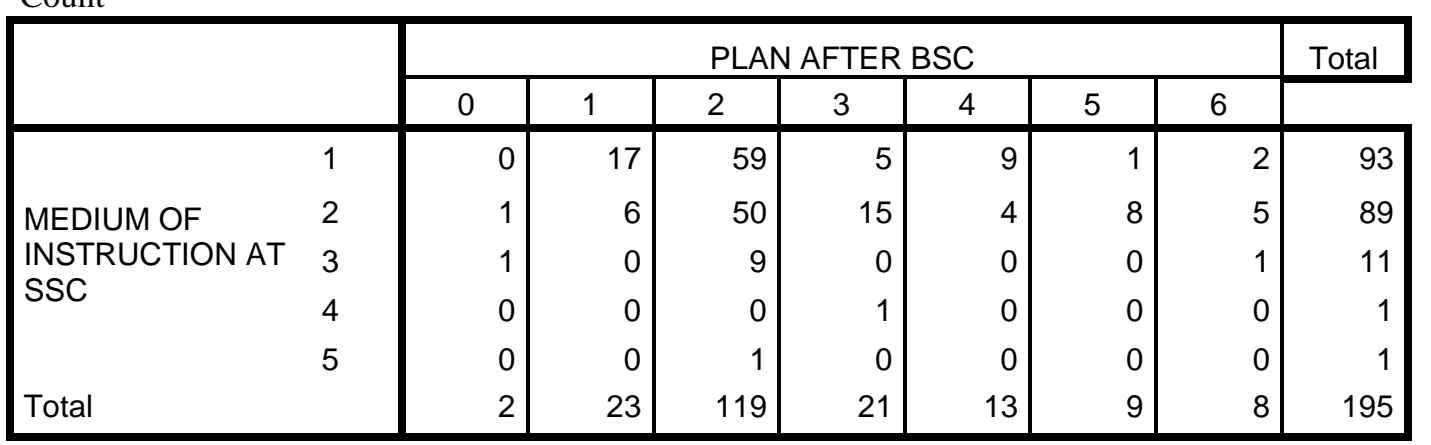

\section{Chi-Square Tests}

\begin{tabular}{|l|r|r|r|}
\hline & \multicolumn{1}{|c|}{ Value } & df & Asymp. Sig. (2-sided) \\
\hline Pearson Chi-Square & $42.748^{a}$ & 24 & .011 \\
Likelihood Ratio & 39.705 & 24 & .023 \\
Linear-by-Linear Association & 2.639 & 1 & .104 \\
N of Valid Cases & 195 & & \\
\hline
\end{tabular}

a. 26 cells $(74.3 \%)$ have expected count less than 5 . The minimum expected count is .01 . 